\title{
A REVIEW OF REMEDIATION AND CONTROL SYSTEMS FOR THE TREATMENT OF AGRICULTURAL WASTE WATER IN IRELAND TO SATISFY THE REQUIREMENTS OF THE WATER FRAMEWORK DIRECTIVE
}

\author{
O. Fenton, M.G. Healy and R.P.O. Schulte
}

\begin{abstract}
In Ireland agricultural activities have been identified as major sources of nutrient input to receiving waters, and it has been estimated that these activities contribute $75.3 \%$ of the $\mathrm{N}$ and $33.4 \%$ of the $\mathrm{P}$ found in these waters. The strategy at European level focuses on the prevention of nutrient loss by improved farm management. However, it does not focus on nutrient remediation or incidental nutrient loss from farmyard manures to surface water and groundwater. This review describes the impact of agriculture on the environment in Ireland and examines emerging technologies for agricultural waste-water treatment. An integrated approach at pretreatment and field stages for nitrate $\left(\mathrm{NO}_{3}\right)$ remediation and $\mathrm{P}$ control is recommended.
\end{abstract}

O. Fenton

(corresponding

author; owen.

fenton@teagasc.ie)

and R.P.O. Schulte,

Environmental

Research Centre,

Teagasc, Johnstown

Castle, Co. Wexford;

M.G. Healy,

Department of Civil

Engineering,

National University of

Ireland, Galway.
Received 18 April 2007. Accepted 15 February 2008. Published 28 August 2008.

\section{INTRODUCTION}

\section{LEGISLATIVE BACKGROUND}

The Surface Water Directive (75/440/EEC: Council of the European Union 1975), the Groundwater Directive (80/68/EEC: Council of the European Union 1980), the Drinking Water Directive (98/ 83/EC: Council of the European Union 1998), the Nitrates Directive (91/676/EEC: Council of the European Union 1991a) and the Urban Waste Water Directive (91/271/EEC: Council of the European Union 1991b) have focused considerable attention on the environmentally safe discharge of agricultural waste waters in Ireland. The Water Framework Directive (WFD) (2000/60/EC: Council of the European Union 2000) came into force on 22 December 2000 and was transposed into Irish legislation by the European Communities (Water Policy) Regulations 2003 on 22 December 2003. Eight river basin districts have been established on the island of Ireland to facilitate the aim of achieving 'good ecological status' in all Irish waterbodies by 2015 .

The WFD will bring about major changes in the regulation and management of Europe's water resources, including, in general, a requirement for the preparation of integrated catchment-management plans that identify point and non-point pollution, water abstraction and land use; the introduction of an EU-wide target of 'good ecological status' for all surface waters and groundwaters; and the planning and implementation of efficient and cost-effective measures to protect groundwaters and surface waters.

\section{AGRICULTURE AND WATER QUALITY IN IRELAND}

In Ireland agriculture is an important national industry that involves approximately 270,000 people, 6.191 million cattle, 4.257 million sheep, 1.678 million pigs and 10.7 million poultry (CSO 2006). The industry utilises $64 \%$ of Ireland's land area (Fingleton and Cushion 1999), of which 91\% is devoted to grass, silage, hay and rough grazing (Department of Agriculture and Food 2003). Grassbased rearing of cattle and sheep dominates the industry (EPA 2004). In 2004 over 60 million tonnes of agricultural waste were generated, of which $60.6 \%$ came from cattle manure and slurry (EPA 2004; Table 1).

Livestock production is associated with external inputs of $\mathrm{N}$ and $\mathrm{P}$, which include chemical fertilisers, soiled waters and slurries. Nitrate $\left(\mathrm{NO}_{3}\right)$ leaching from waste-water irrigation is dependent on the hydraulic loading rate, soil water content and soil type (Ryan 1998). Since both $\mathrm{NO}_{3}$ and soil have negative electrostatic charges, $\mathrm{NO}_{3}$ in solution tends not to be taken up by the soil below the rooting depth, and instead travels through the soil, leading to increased potential for $\mathrm{NO}_{3}$ groundwater contamination (Abu-Ashor et al. 1994; Kung et al. 2000). The increases in dissolved $P$ concentrations in rivers and streams have been linked - through 
overland flow and erosion losses - to the accumulation of excess soil $\mathrm{P}$ in these catchments under intensive animal production (Boesch et al. 2001). Daly et al. (2001) examined the sorption capacity and desorption dynamics in Irish grassland soils and found that high-organic-matter soils have low $\mathrm{P}$ sorption capacities and poor $\mathrm{P}$ reserves compared with mineral soils, resulting in $\mathrm{P}$ losses from these organic soils where $\mathrm{P}$ amendments exceed crop needs (Daly et al. 2001).

Nutrient losses to surface water and groundwater may have an adverse impact on the biodiversity and ecology of aquatic agri-environment ecosystems (Schulte 2006). Agricultural nutrient inputs are the most significant nutrient load entering receiving waters in Ireland, and they have been estimated to comprise $75.3 \%$ of the $\mathrm{N}$ load and $33.4 \%$ of the $\mathrm{P}$ load in these waters (River Basin Districts 2005). A survey of 1,132 rivers and streams from 2001 to 2003 (Toner et al. 2005) estimated that the percentage of pollution attributed to agriculture was approximately $32 \%$ in rivers and streams that were slightly or moderately polluted, but only $15 \%$ in those that were seriously polluted. Other studies indicate that diffuse $\mathrm{P}$ losses from agriculture may contribute to eutrophication (Clabby et al. 1992; Bowman et al. 1996; Lucey et al. 1999; McCarrigle et al. 2002).

At present, the European strategy to restore the 'good ecological status' of surface water and groundwater focuses on reducing further nutrient loss to these waterbodies. Results from a Water4all (2005) project suggest that regulation alone may not achieve sufficient improvement in water quality in soils and groundwater aquifers in an acceptable time frame and that there may be a need for moreaccelerated solutions.

\section{Table 1-Estimated agricultural, organic managed-waste generation in 2001 (EPA 2004).}

\begin{tabular}{lrr}
\hline Waste category & $\begin{array}{c}\text { Waste generation } \\
\text { (tonnes wet weight) }\end{array}$ & $\%$ \\
\hline Cattle manure and & & \\
$\quad$ slurry & $36,443,603$ & 60.6 \\
Water (dairy only) & $18,377,550$ & 30.5 \\
Pig slurry & $2,431,819$ & 4.0 \\
Silage effluent & $1,139,231$ & 1.9 \\
Poultry litter & 172,435 & 0.3 \\
Sheep manure & $1,336,336$ & 2.2 \\
Spent mushroom & 274,050 & 0.5 \\
$\quad$ compost & & \\
& & 100 \\
\hline
\end{tabular}

The objective of this paper is to examine the potential of emerging technologies for agricultural waste-water treatment in Ireland to satisfy the requirements of the WFD.

\section{CURRENT MEASURES FOR THE PROTECTION OF WATERS}

Traditionally, agricultural wastes are disposed of by land spreading. In land spreading the recharge rate, time of year of application, hydraulic conductivity of the soil, soil water content, depth of soil to the water table and/or bedrock, and concentration of nutrients and suspended sediment in the waste water (soiled water and any discharge containing nutrients) are some of the defining parameters that determine $\mathrm{NO}_{3}$ movement through the soil to the water table. The recommended maximum rate of application is $5 \mathrm{~mm}$ per $\mathrm{h}$, and the quantity applied should not exceed $50 \mathrm{~m}^{3}$ per ha per application (Agricultural Development and Advisory Service 1985).

\section{PRETREATMENT AND IN SITU AMENDMENTS}

\section{ALUM AND POLYACRYLAMIDE}

Aluminium sulphate (alum) and polyacrylamide (PAM) are chemical flocculants commonly used in water-treatment plants to remove $\mathrm{P}$ and suspended sediment. They can be used as pretreatment and in situ amendments for agricultural waste-water amelioration. Alum should be applied to water or waste water in a $\mathrm{pH}$ range of 5.5-9.0, as it is nontoxic in this range. The final concentration of alum in drinking-water distribution systems and receiving waters should remain below $200 \mu \mathrm{g}$ Al $1^{-1}$, as this is the safe upper-limit concentration of Al for drinking water (WHO 2003). PAM causes suspended particles to join and form aggregates, which then rapidly settle out of suspension in filterable sizes, thereby removing particulate $\mathrm{P}$ from solution (Adin and Asano 1998). The soilstabilising and flocculating properties of PAM improve run-off water quality by reducing sediments, $\mathrm{N}$, dissolved reactive $\mathrm{P}$ (DRP) and total $\mathrm{P}(\mathrm{TP})$, chemical oxygen demand, pesticides, weed seeds and micro-organisms in run-off (Sojka et al. 2007).

\section{Alum and PAM for farm water treatment}

The direct addition of alum or PAM to farm waste water before land application may reduce the risk of nutrient loss to surface waters. The addition of alum sludge directly to soil prior to land spreading of waste water may also be a viable option to control $\mathrm{P}$. 
To date, the use of chemical amendments has been investigated mainly in poultry-litter studies (Moore et al. 1999; Moore and Edwards 2005; 2007). The US Department of Agriculture has made the use of alum a conservation standard practice in several states (Moore and Edwards 2005), and about 700800 million broilers per year are grown with alum in the US (P.A. Moore, pers. comm.). Some limited work is being undertaken to investigate chemical additions to dairy waste water (McFarland et al. 2003). In Ireland no study has investigated the use of alum for waste-water treatment. Therefore, issues relating to $\mathrm{Al}$ release to surface waters need to be investigated.

Sims and Luka-McCafferty (2002) used alum as a poultry-litter amendment (application rate $0.11 \pm$ $0.01 \mathrm{~kg}$ alum per bird) on a farm-scale study. Alum was applied every six weeks to the litter before land spreading, after removal of each flock of broilers for processing. This alum amendment decreased litter $\mathrm{pH}$ (control $7.8 \pm 0.3$ to amended $7.2 \pm 0.3$ ) and the solubility of $\mathrm{P}(1,475 \pm 492$ to $405 \pm 192 \mathrm{mg}$ $\left.\mathrm{kg}^{-1}\right)$, inorganic arsenic $\left(19 \pm 4\right.$ to $\left.7 \pm 3 \mathrm{mg} \mathrm{kg}^{-1}\right)$, copper $\left(272 \pm 50\right.$ to $\left.172 \pm 45 \mathrm{mg} \mathrm{kg}^{-1}\right)$ and zinc $\left(29 \pm 7\right.$ to $\left.15 \pm 10 \mathrm{mg} \mathrm{kg}^{-1}\right)$. Similar results were reported by Moore et al. (1998), who applied alum to poultry litter at a rate of $0.091 \mathrm{~kg}$ per bird (corresponding to $10 \%$ alum by weight of the broiler litter). In this study reduced litter $\mathrm{pH}$ and decreased $\mathrm{NH}_{3}$ volatilisation from the litter resulted in atmospheric $\mathrm{NH}_{3}$ reductions of $97 \%$ after four weeks in alum-amended houses.

Moore and Edwards (2005) also investigated the effects of alum addition to poultry litter on $\mathrm{Al}$ in run-off from 52 randomised $1.52 \mathrm{~m} \times 3.05 \mathrm{~m}$ plots. Over a ten-year study, the application rates of alum-treated broiler litter were 65, 130, 195 and $260 \mathrm{~kg} \mathrm{~N} \mathrm{ha}^{-1}$. Total and soluble Al concentrations

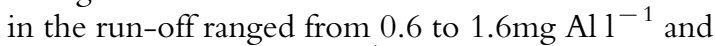
from 0.1 to $0.2 \mathrm{mg} \mathrm{Al}^{-1}$, respectively. Udeigwe et al. (2007) also found that alum-amended litter can reduce the amount of water soluble $\mathrm{P}$ (WSP) in surface run-off water. Moore et al. (1999) reported WSP concentrations ranging from 15 to $40 \mathrm{mg}$ P $\mathrm{kg}^{-1}$ in soils fertilised with unamended poultry litter at application rates of 2.24 to $8.98 \mathrm{Mg} \mathrm{ha}^{-1}$. Alum-amended litter, applied at rates ranging from 65 to $265 \mathrm{~kg} \mathrm{~N} \mathrm{ha-1,} \mathrm{produced} \mathrm{soil} \mathrm{WSP}$ concentrations similar to unfertilised soilsapproximately $20 \mathrm{mg} \mathrm{P} \mathrm{kg}^{-1}$ — in this same study.

The use of alum as a soil amendment increases the binding potential of soils and is effective in immobilising soluble P (McFarland et al. 2003; Zvomuya et al. 2006). McFarland et al. (2003) applied $20 \mathrm{~mm}$ of dairy waste water $(875 \mathrm{mg}$ total $\mathrm{N}$ (TN) $1^{-1}$, 87mg TP $1^{-1}$, 4.4mg $\mathrm{PO}_{4}-\mathrm{P}^{-1}$, $244 \mathrm{mg} \mathrm{NH}_{3}-\mathrm{N} \mathrm{1}^{-1}, 244 \mathrm{mg} \mathrm{Al} 1^{-1}$ and $\mathrm{pH} 7.9$ ) to three $2.5 \mathrm{~m} \times 3 \mathrm{~m}$ plots: a control plot $(5.4 \%$ slope), a plot amended with alum (alum dosage 521.6g; 6.4\% slope) and a plot amended with gypsum (gypsum dosage 576g; 5.9\% slope). Under a rainfall intensity of $76.2 \mathrm{~mm} \mathrm{~h}^{-1}$, the alumamended plot had maximum $\mathrm{TP}$ and $\mathrm{PO}_{4}-\mathrm{P}$ concentrations in surface run-off of 14.3 and $0.07 \mathrm{mg}^{-1}$, respectively; pre-application surface run-off concentrations were 13.3 and $0.66 \mathrm{mg}^{-1}$, respectively. Post-application $\mathrm{TP}$ and $\mathrm{PO}_{4}-\mathrm{P}$ concentrations from the gypsum-amended plot were 11.1 and $0.57 \mathrm{mg}^{-1}$, respectively; preapplication surface run-off $\mathrm{TP}$ and $\mathrm{PO}_{4}-\mathrm{P}$ concentrations were 12.1 and $0.54 \mathrm{mg} 1^{-1}$, respectively. The Al concentration in the surface run-off water from the alum-amended plot was $314 \mathrm{mg}^{-1}-30 \%$ more than the pre-application $\mathrm{Al}$ run-off concentration of $220 \mathrm{mg}^{-1}$. The authors did not measure soluble $\mathrm{Al}$ in this study, but the soils contained about 5,000 to $6,000 \mathrm{ppm} \mathrm{Al} \mathrm{before}$ any alum was added (A.M.S. McFarland, pers. comm.).

Other studies using alum buffer strips have shown reductions in run-off DRP of up to $86 \%$ (Peters and Basta 1996; Basta and Storm 1997; Gallimore et al. 1999; Haustein et al. 2000; Dayton et al. 2003). Dayton and Basta (2005) applied poultry litter at a rate of $8.8 \mathrm{Mg} \mathrm{ha}^{-1}$ to the upper $75 \%$ area of a $0.5 \mathrm{~m}$-wide by $1 \mathrm{~m}$ long flume, inclined at a slope of $5 \%$. In the remaining $25 \%$ of the downslope flume area airdried water-treatment residue (WTR) (Al range 1.39-165 $\mathrm{g} \mathrm{kg}^{-1}$ ) was applied to a buffer strip at rates of 0 (the control), 5, 10 and $20 \mathrm{Mg} \mathrm{ha}^{-1}$. Under rainfall intensities of $70 \mathrm{~mm} \mathrm{hr}^{-1}$, applied for 30min, the mean DRP concentration in the control studies was $31.1 \mathrm{mg} \mathrm{l}^{-1}$. For WTR additions of 5, 10 and $20 \mathrm{Mg} \mathrm{ha}^{-1}$, mean DRP in the surface runoff was reduced by 37.6, 50.5 and $86.2 \%$, respectively.

PAM has also been used to separate solid and liquid components of swine manure. Optimum PAM dosage rates vary with the amount of suspended solids (SS) in the liquid manure-26 and $79 \mathrm{mg} \mathrm{PAM}^{-1}$ for samples containing 1.5 and $4.1 \mathrm{~g}$ total SS $1^{-1}$, respectively, have achieved 90 to 94\% removals (Vanotti and Hunt 1999).

PAM greatly reduces irrigation-induced erosion on furrow-irrigated fields, while sediment ponds can be constructed to remove suspended sediment from irrigation run-off, with seasonal application rates of $1 \mathrm{~kg}$ PAM ha ${ }^{-1}$ (furrow subsurface irrigation) to $5 \mathrm{~kg}$ PAM ha ${ }^{-1}$ (sprinkler irrigation) (Lentz and Sojka 1992). Application rates of $1 \mathrm{~kg}$ PAM ha ${ }^{-1}$ should be applied after first cultivation to reduce furrow irrigation-induced erosion, with an additional $0.5-1 \mathrm{~kg} \mathrm{ha}^{-1}$ for the next three irrigations. An initial dose of PAM at $10 \mathrm{mg}^{-1}$ in irrigation inflows during the furrow advance period may achieve 93\% reduction in sediment loss (Lentz and Sojka 1992). 
Alum and PAM for surface waters

Alum and PAM may also be used to reduce the SS and nutrient concentration of surface waters. Nutrient-rich agricultural waste water has caused eutrophication in the Salton Sea, California (Mason et al. 2005). The removal of dissolved $\mathrm{P}$ and P-laden sediment from this water using non-ionic PAM $\left(2 \mathrm{mg} \mathrm{l}^{-1}\right)$ and alum $\left(4 \mathrm{mg} \mathrm{l}^{-1}\right)$ - added to ditches receiving tributary waters - substantially reduced SS and turbidity in low-energy systems (velocity gradients $<10 \mathrm{~s}^{-1}$ ) by $95 \%$ and soluble $\mathrm{P}$ by $93 \%$. Best results are obtained when PAM and alum are used in conjunction with settlement basins or lowflow regimes.

\section{OCHRE}

Deposits of ochre, a ferric oxyhydroxide precipitate, can occur from acid mines, and these deposits can be ecologically devastating (Gray 1996). The sorption capacity of ochre to sequester $\mathrm{P}$ ranges from $0.5 \mathrm{~g} \mathrm{P}$ $\mathrm{kg}^{-1}$ to $2 \mathrm{~g} \mathrm{P} \mathrm{kg}^{-1}$ (Bozika 2001) and is site-specific (Heal et al. 2005). Preliminary studies on the Psorption capacity of ochre from the AvocaAvonmore river catchment in the south-east of Ireland suggest that it is capable of adsorbing up to $16 \mathrm{~g} \mathrm{PO}_{4}-\mathrm{P} \mathrm{kg}^{-1}$ (Fenton et al. 2007). The Padsorption capacity of ochre compares very favourably with other low-cost media (Table 2). The potential for ochre to reduce $\mathrm{P}$ from soiled water is high and, if used in conjunction with biofilters, may provide an efficient means of treating soiled water. Ochre-P pellets, developed by the University of Newcastle in the UK (Heal et al. 2005), allow in situ applications of ochre at specific

Table 2-Maximum adsorption capacities of different media (based on Mann 1997; Heal et al. 2005).

\begin{tabular}{lc}
\hline Amendment & $\begin{array}{c}\text { Maximum adsorption capacity } \\
\left(g^{-1} \mathrm{~kg}^{-1}\right)\end{array}$ \\
\hline Danish sands & $0.02-0.13$ \\
Gravel & $0.03-0.05$ \\
Bottom ash & 0.06 \\
Steel-furnace slag & $0.38-1.4$ \\
Blast-furnace slag & $0.05-0.65$ \\
Fly ash & 0.62 \\
Shale & 0.75 \\
Laterite & $0.75-1.38$ \\
Zeolite & $1-2.2$ \\
Serpentinite & 1 \\
Electric-arc- & \\
furnace steel slag & 2.2 \\
Polkemmet ochre & 26 \\
Minto ochre & 30.5 \\
\hline
\end{tabular}

locations (P-stripping zones) on a farm, without discoloration of water. They absorb $\mathrm{P}$ from solution and may be used in the remediation of waste waters from different sources, such as agricultural run-off. Exhausted pellets may then be pulverised and applied as fertiliser. As $\mathrm{P}$ desorption from saturated ochre is $<1 \%$ (Fenton et al. 2007), ochre may be used in surface water and replaced when saturated.

\section{RELEVANCE AND APPLICABILITY OF ALUM, PAM AND OCHRE FOR IRELAND}

The EU Sewage Sludge Directive (86/278/EEC; Council of the European Union 1986) specifies limit values for maximum concentrations of heavy metals in soil and sludge and limit values for maximum annual quantities of heavy metals introduced to the soil (Table 3). The Code of good practice for the use of biosolids in agriculture (Department of the Environment, Heritage and Local Government 1999) sets new standards for treatment of biosolids. These standards are broadly in line with the USEPA Class A standard. Biosolids that meet such standards must have very low pathogen content and low metal content, and the organic matter must be stabilised so that there is little odour or possibility of attracting pests that spread disease. Such 'exceptional quality biosolids' can be used on the farm without a site permit or can be sold to consumers for garden use. This presents new challenges for the optimisation of sludge treatment and final effluent quality. However, not all sludge is suitable for land application. In a study in the south east of Ireland $21 \%$ of soils breached the provisions of the EU Sewage Sludge Directive for heavy metals before any sludge application (McGrath and McCormack 1999). This, coupled with the suitability and availability of tillage lands, poses problems for sludge application.

With $90 \%$ of all sludge coming from agriculture, the addition of alum or PAM to farm waste water before land application would reduce

Table 3-Limit values for concentrations of heavy metals in soil and sludge, for agricultural use (Council of the European Union 1986).

\begin{tabular}{lcc}
\hline Parameters & $\begin{array}{c}\text { Soil } \\
\left(m^{-1} \mathrm{~kg}^{-1}\right)\end{array}$ & $\begin{array}{c}\text { Sludge } \\
\left(m g \mathrm{~kg}^{-1}\right)\end{array}$ \\
\hline Cadmium & 1 & 20 \\
Copper & 50 & 1,000 \\
Nickel & 30 & 300 \\
Lead & 50 & 750 \\
Zinc & 150 & 2,500 \\
Mercury & 1 & 16 \\
\hline
\end{tabular}


the risk of nutrient loss to surface waters. This could be done in various ways: direct alum or PAM application to soil, simultaneous application during land spreading or prior application to storage facilities. Another option is to apply alum and PAM in buffer strips. Ochre could be applied in conjunction with alum and PAM to sequester $\mathrm{P}$ after precipitation of solids has occurred. However, the possibility of heavy-metal loss in surface run-off needs to be further investigated.

\section{EMERGING TECHNOLOGIES FOR WASTE- WATER TREATMENT}

\section{N REMOVAL}

Conventional methods have been used to remediate $\mathrm{NO}_{3}$ contamination, including monitored natural attenuation (American Society for Testing and Materials 1998); pump-and-treat (USEPA 1990), wherein treated water is used to irrigate crops; pump-and-waste (USEPA 1990), wherein contaminated water is evaporated or injected into a saline aquifer or geological unit; and phytoremediation (Suresh and Ravishanker 2004). However, pumpand-treat is expensive, and pump-and-waste is unsustainable and causes plume migration.

New and emerging pretreatment remediation technologies, such as continuously moving biofilm reactors (Rodgers and Burke 2002), sequencing batch biofilm reactors (Rodgers et al. 2004), trickling filters (Kuai et al. 1999), activated sludge systems (Gao et al. 2004), fluidised-bed biofilm reactors (Rabah and Dahab 2004) and rotating biological contractors (Ayoub and Saikaly 2004), have shown good potential for biological $\mathrm{N}$ removal from domestic and agricultural waste waters. These technologies may be used to remediate dairy-parlour washings and soiled water and may reduce storage volumes and associated costs.

\section{Permeable reactive barriers}

Low-cost, in situ treatment systems, called permeable reactive barriers (PRBs), may be used to treat groundwater. PRBs are defined as 'an emplacement of reactive materials in the subsurface designed to intercept a contaminant plume, provide a flow path through the reactive media, and transform the contaminants into environmentally acceptable forms to attain remediation concentration goals down-gradient of the barrier' (Powell and Powell 1998). In situ subsurface denitrification trenches, wherein waste water flows through a C-rich mixture to reduce $\mathrm{NO}_{3}$ concentrations, are PRBs adapted for agricultural use (Healy et al. 2006). Organic-C amendments offer low-cost surface and subsurface treatment alternatives for waste water.

Four types of PRB exist: (1) a funnel-and-gate system used primarily for halogenated hydrocarbons, aromatic compounds and heavy-metal remediation; (2) an injection-well configuration, where a reactive wall is generated through injection of a reactive solution; (3) passive collection with reactor cells, where contaminated water is drained to a reactive zone; and (4) a shallow continuous trench used for $\mathrm{NO}_{3}$ remediation. Horizontal-flow (Erickson et al. 1974) or vertical-flow (Robertson and Cherry 1995) denitrification trenches that use a solid C source (woodchips) as the filter media have been used in Australia, Canada, the US and New Zealand (Foundations for Water Research 2004).

\section{Reactive materials for PRBs}

Denitrification may be increased in soils by the addition of an external $\mathrm{C}$ amendment. This C amendment could include woodchips, wheat straw, corn, vegetable oil, sawdust mulch, treated newspaper or unprocessed cotton (Volokita et al. 1996). In situ treatment may involve material being used separately or mixed with soil or sand. Different media have different denitrification rates (Table 4). Sawdust has high denitrification rates due to its large surface area, but it is prone to clogging. After barrier construction, Schipper et al. (2004) measured saturated hydraulic conductivities of $0.48 \mathrm{~m} \mathrm{day}^{-1}$ and $65.4 \mathrm{~m}$ day $^{-1}$ in a PRB sawdust wall and aquifer, respectively; at these conductivities, groundwater flowed under, rather than through, the reactive media. Another disadvantage of sawdust is its low durability over time (Horn et al. 2006).

Healy et al. (2006) examined the use of various wood materials as $\mathrm{C}$ sources in laboratory horizontal-flow filters to denitrify $\mathrm{NO}_{3}$ from a synthetic waste water. The filter materials were sawdust (from Pinus radiata), sawdust and soil, sawdust and sand, and medium-chip woodchips and sand. Two influent $\mathrm{NO}_{3}-\mathrm{N}$ concentrations, $200 \mathrm{mg} \mathrm{l}^{-1}$ and $60 \mathrm{mg} \mathrm{l}^{-1}$, loaded at 2.9 to $19.4 \mathrm{mg}$ $\mathrm{NO}_{3}-\mathrm{N} \mathrm{kg}{ }^{-1}$ mixture $\mathrm{d}^{-1}$, were used. The horizontal-flow filter with a woodchip/sand mixture, loaded at $2.9 \mathrm{mg} \mathrm{NO}_{3}-\mathrm{N} \mathrm{kg}^{-1} \mathrm{~d}^{-1}$, performed best, yielding a $97 \%$ reduction in $\mathrm{NO}_{3}-\mathrm{N}$ at steady-state conditions. Greenan et al. (2006) investigated four different C sourcesmixed with C-to-soil volume ratios of 1 -in anaerobic batch experiments, as follows: (i) 3$10 \mathrm{~cm}$-long woodchips (predominately Quercus spp.), (ii) woodchips saturated with soybean oil (48\% oil by weight), (iii) dried corn stalks collected after harvest and (iv) paper fibres from corrugated cardboard. Over a 180-day study period, denitrification rates ranged from $0.427 \mathrm{~g} \mathrm{~N} \mathrm{~kg}^{-1}$ substrate $\mathrm{d}^{-1}$ for the ground corn stalks to $0.066 \mathrm{~g} \mathrm{~N}$ $\mathrm{kg}^{-1}$ substrate $\mathrm{d}^{-1}$ for the woodchips. 
Table 4-Solid carbon reactive media and nitrate-removal rates.

\begin{tabular}{|c|c|c|c|c|c|}
\hline Reference & $\begin{array}{l}\text { Experiment } \\
\text { type }\end{array}$ & $\begin{array}{c}\text { Influent } \mathrm{NO}_{3}-\mathrm{N} \\
\text { concentration } \\
\left(m g l^{-1}\right)\end{array}$ & $\begin{array}{c}\text { Media } \\
(\% \text { by volume })\end{array}$ & $\begin{array}{l}\text { Residence time } \\
\text { (days) }\end{array}$ & $\begin{array}{c}\mathrm{NO}_{3}-\mathrm{N} \\
\text { removal rate } \\
(\%)\end{array}$ \\
\hline Healy et al. 2006 & Lab column & 60 & Woodchip (50\%) & - & 97 \\
\hline \multirow[t]{2}{*}{ Fahner 2002} & Field study & 63 & Sawdust $(30 \%)$ & $3.5-7$ & 76 \\
\hline & Lab column & 12 & Sawdust $(30 \%)$ & $0.5-7$ & 40 \\
\hline $\begin{array}{l}\text { Carmichael } 1994 \\
\text { Schipper and } \\
\text { Vojvodić-Vuković }\end{array}$ & Lab column & $50-87$ & Woodchip (100\%) & 1.6 & $72-83$ \\
\hline 2001 & Field study & $5-15$ & Sawdust $(30 \%)$ & - & 95 \\
\hline \multirow[t]{2}{*}{$\begin{array}{l}\text { Robertson et al. } \\
2000\end{array}$} & Field study & 57 & $\begin{array}{l}\text { Waste cellulose }{ }^{1} \\
(15 \%)\end{array}$ & 17 & 80 \\
\hline & Field study & 1.2 & $\begin{array}{l}\text { Waste cellulose } \\
(15 \%)\end{array}$ & 30 & 83 \\
\hline
\end{tabular}

\footnotetext{
${ }^{1}$ Waste cellulose $=$ wood mulch, sawdust, leaf compost.
}

\section{Implementation of PRBs}

In PRBs the reactive material is placed in a trench, which is sealed to surface level with clay to avoid surface-subsurface cross-contamination and to achieve anaerobic conditions. The reactive zone must have a higher conductivity than the surrounding soil to encourage flow into the reactive zone (Simon and Meggyes 2000). Filter gravel should be placed at the edges of the reactive zone to stop small particles washing into and clogging the trench. Geotechnical aspects, such as subsurface soil strength and the presence of cobbles, should be considered. A temporary piezometer network or ground-penetrating radar survey should be utilised to identify the location and movement of the migrating nutrient plume on-site. Trenches oriented perpendicular to groundwater flow direction, taking annual deviations into consideration, should be placed at various depths, depending on average water-table heights. They should also be placed at strategic positions near potential point sources of pollution, soiled water installations and slurry and silage facilities and along shallow groundwater zones adjacent to riparian zones, ditches or open waterways (Seong-Chun et al. 2005).

The time frame for site evaluation, hydrogeological study, engineering design and implementation could be from 14 to 30 weeks (Kalin 2004). Irish farmers, under the Rural Environment Protection Scheme, must leave a $1.5 \mathrm{~m}$-wide buffer strip of uncultivated land beside watercourses. Buffer strips may have a positive effect on $\mathrm{P}$ and pesticide loss, as low soil $\mathrm{P}$ concentration and permanent cover 'trap' P. A trench placed at such a location integrates nutrient remediation and control and could potentially cut down on the design and implementation time frame. A methodology suitable for
Irish conditions that deals with the location, construction, ideal trench type, dimensional criteria and monitoring of a PRB from a point source has been devised (Fenton et al. in press). The long-term performance of PRBs needs to be assessed.

\section{WILLOW AND REED PLANTATIONS}

Willows (Salix spp.) are also gaining in popularity in Ireland and elsewhere for the treatment of domestic and agricultural waste water (Rosenqvist and Dawson 2005; Börjesson and Berndes 2006). A long growing season and a high nutrient-retention capacity make them ideal for waste-water treatment (Dimitriou and Aronsson 2004). The Landfill Directive (99/31/EC: Council of the European Union 1999) forces local authorities to reduce the volume of organic waste disposed of in landfills. To date, willows have been viewed as an alternative, environmentally friendly energy source to satisfy the greenhouse gas-emission requirements of the Kyoto Protocol (Rice 2003).

Willows assimilate nutrients into plant biomass. They remove pollutants by directly assimilating them into their tissue. Biomass production in willows is dependent on the amount of $\mathrm{N}, \mathrm{P}$ and $\mathrm{K}$ that is applied to the soil (Hodson et al. 1993).

Willows are normally planted in rows, with $0.75-1.5 \mathrm{~m}$ distances between rows and $0.5-0.6 \mathrm{~m}$ distances between trees along each row, and they are harvested every 3-5 years (Aronsson et al. 2002). Sludge can be allowed to percolate between the willow rows through a dripirrigation system, normally applied at a rate of $80 \mathrm{~kg} \mathrm{~N} \mathrm{ha} \mathrm{yr}^{-1}$ (Aronsson et al. 2002). 
Nutrients are permanently removed from the system by annual harvesting.

Compared to conventional waste-water treatment, waste-water irrigation of willow plantations can offer great savings. Dawson (2004) estimated that a willow area of approximately 3,000 ha would be required for the disposal of all domestic sewage sludge in Ireland. Rosenquist and Dawson (2005) calculated that savings of around $€ 7-18 \mathrm{~kg}^{-1}$ $\mathrm{N}$ could be made in a willow irrigation system compared to a conventional waste-water treatment plant.

In Sweden waste-water irrigation of willow plantations is now commonly used (Perttu 1998; Dimitriou and Aronsson 2004; Lindoff Communications Ltd 2004; Dimitriou and Aronsson 2005), and hydraulic loading rates of up to $600 \mathrm{~mm} \mathrm{yr}^{-1}$, yielding $125 \mathrm{~kg} \mathrm{~N}^{-1}$, may be applied without the risk of $\mathrm{N}$ leaching to groundwater (Börjesson 1999). In Kågeröd, southern Sweden, biologically treated waste water from a population equivalent of 5,000 was used for irrigation on an 11 ha willow plantation (Lindoff Communications Ltd 2004). Waste water was applied from May to October at an average rate of $4-5 \mathrm{~mm} \mathrm{~d}^{-1}\left(730-770 \mathrm{~mm} \mathrm{yr}^{-1}\right)$, giving average yearly $\mathrm{N}$ and $\mathrm{P}$ application rates of $72 \mathrm{~kg} \mathrm{~N}$ ha ${ }^{-1}$ $\mathrm{yr}^{-1}$ and $10 \mathrm{~kg} \mathrm{P} \mathrm{ha}^{-1} \mathrm{yr}^{-1}$, respectively. Average TN, TP and biochemical oxygen demand concentrations were reduced by $79 \%, 11 \%$ and $55 \%$, respectively. Evapotranspiration was not measured in this study.

Regular fertilisation and irrigation increases the biomass and the nutrient retention within the willow shoot. In a study conducted in New York Adegbidi et al. (2001) found that under annual nutrient-application rates of $224 \mathrm{~kg} \mathrm{~N}^{-1}, 112 \mathrm{~kg}$ $\mathrm{P} \mathrm{ha}^{-1}$ and $224 \mathrm{~kg} \mathrm{~K} \mathrm{ha}^{-1}$, drip irrigated at 20$60 \mathrm{~mm} \mathrm{wk}^{-1}$ during the growing season, between $2.5 \mathrm{Mg} \mathrm{ha}{ }^{-1} \mathrm{yr}^{-1}$ (for non-irrigated plots) and $27.5 \mathrm{Mg} \mathrm{ha}{ }^{-1} \mathrm{yr}^{-1}$ (for irrigated plots) of biomass was produced from willows. Biomass-production rates of Phragmites australis (Cav.) Trin. ex Steudel, a plant commonly used in constructed wetlands (CWs) for the treatment of waste water, are within this range. Karunaratne et al. (2004) investigated the effects of harvesting $P$. australis in a wetland in Central Japan and found that biomass levels rose to $1,250 \mathrm{~g} \mathrm{~m}^{-2}$ (approximately $12.5 \mathrm{Mg}$ $\mathrm{ha}^{-1}$ ) in July. Similar figures have been found in Ireland (Healy et al. 2007). P. australis does appear to have a greater ability to remove $\mathrm{N}$ and $\mathrm{P}$, however. In a CW in Ireland Healy et al. (2007) measured maximum nutrient retentions of approximately $15.5 \mathrm{mg} \mathrm{N} \mathrm{g}^{-1}$ dry weight (DW) and $1.6 \mathrm{mg} \mathrm{P} \mathrm{g}^{-1} \mathrm{DW}$ in $P$. australis. In a wetland planted with $P$. australis in north-east Italy Bragato et al. (2006) measured maximum $\mathrm{TN}$ and $\mathrm{TP}$ concentrations of $27 \mathrm{mg} \mathrm{N} \mathrm{g}^{-1} \mathrm{DW}$ and $0.8 \mathrm{mg} \mathrm{P}$ $\mathrm{g}^{-1} \mathrm{DW}$ in July. These values are far in excess of the measurements conducted by Adegbidi et al. (2001), where maximum nutrient retentions of $3.7-7.2 \mathrm{mg} \mathrm{N} \mathrm{g}^{-1} \mathrm{DW}$ and $0.6-0.7 \mathrm{mg} \mathrm{P} \mathrm{g}^{-1}$ DW were measured in willows.

\section{REMEDIATION OPTIONS FOR AGRICULTURE IN IRELAND}

To meet the requirements of the Nitrates and WFD directives, groundwater and surface-water remediation technologies are needed to capture nutrient loss where nutrient management fails. An integrated approach is needed to address multiple simultaneous challenges of $\mathrm{N}$ and $\mathrm{P}$ losses. Consequently, in situ treatment and pretreatment of farmyard manures should integrate $\mathrm{N}$ remediation and $\mathrm{P}$ control.

Low-cost, low-management remediation technologies, such as PRBs and willows, have good potential in Ireland because they can be implemented at farm level. As woodchip alone and woodchip mixed with soil/sand barriers may result in $\mathrm{NO}_{3}$ removal and, depending on the hydraulic loading rate, may have a long lifespan, the growth of willow plantations to provide a $\mathrm{C}$ source for PRBs should be investigated. Batch and column experiments investigating the denitrification rates and required retention times in PRBs for achieving water-quality targets of different solid C media should be examined. A decision-support system should be developed to provide guidelines to farmers on the location of PRBs, available and suitable reactive media, and associated costs.

Buffer strips, amended with ochre, or willow plantations may also be used to treat surface water and run-off. Mitigation measures that utilise existing agricultural infrastructure, such as open drains and farmyard outlets, and divert drainage and run-off water to reactive cells, then trap sediment (particulate $\mathrm{P}$ ) and sequester soluble $\mathrm{P}$, should be considered.

Specifications for the implementation of these technologies on-site should be developed, and future national policy needs to change to incorporate remediation technologies. Further work should compare the cost-benefit of implementing the alternative remedial technologies and estimate the economic value of such improvements on the ecology of Irish rivers.

\section{CONCLUSIONS}

Current legislation is focused on prevention of nutrient losses from agricultural sources. Remediation and control technologies are recommended to account for incidental losses. 
Waste products, such as alum from water treatment and ochre from acid-mine waste water, should be investigated for use in $\mathrm{P}$ control in surface water and dirty water. The release of heavy metals from these chemical amendments should be investigated on different soil types to address WHO drinking-water guidelines.

Options for $\mathrm{NO}_{3}$ removal include in situ denitrification trenches and willow plantations.

\section{REFERENCES}

Abu-Ashor, J., Joy, D.M., Lee, H., Whiteley, H.R. and Zelin, S. 1994 Transport of microorganisms through soil. Water, Air and Soil Pollution 75, 141-58.

Adegbidi, H.G., Volk, T.A., White, E.H., Abrahamson, L.P., Briggs, R.D. and Bickelhaupt, D.H. 2001 Biomass and nutrient removal by willow clones in experimental bioenergy plantations in New York State. Biomass and Bioenergy 20, 399-411.

Adin, A. and Asano, T. 1998 The role of physicalchemical treatment in wastewater reclamation and reuse. Water Science and Technology 37 (10), 79-90.

Agricultural Development and Advisory Service 1985 Dirty water disposal on the farm. Booklet 2390. London. Ministry of Agriculture, Fisheries and Food.

American Society for Testing and Materials 1998 Standard guide for remediation of ground water by natural attenuation at petroleum release sites. E1943-98. Pennsylvania. ASTM International.

Aronsson, P., Heinsoo, K., Perttu, K. and Hasselgren, K. 2002 Spatial variation in above-ground growth in unevenly wastewater-irrigated willow Salix viminalis plantations. Ecological Engineering 19, 281-7.

Ayoub, G.M. and Saikaly, P. 2004 The combined effect of step-feed and recycling on RBC performance. Water Research 38, 3009-16.

Basta, N.T. and Storm, D.E. 1997 Use of alum residuals to reduce nutrient run-off from agricultural land treated with animal manures to protect surface water quality. In Proceedings, Water residuals and biosolids management: approaching the year 2000, Philadelphia, 3-6 August 1997. Alexandria, Virginia. Water Environment Federation.

Boesch, D.F., Brinsfield, R.B. and Magnien, R.E. 2001 Chesapeake Bay eutrophication: scientific understanding, ecosystem restoration, and challenges for agriculture. Journal of Environmental Quality 30, 303-484.

Börjesson, P. 1999 Environmental effects of energy crop cultivation in Sweden. Part I. Identification and quantification. Biomass and Bioenergy 16, 13754.

Börjesson, P. and Berndes, G. 2006 The prospects for willow plantations for wastewater treatment in Sweden. Biomass and Bioenergy 30, 428-38.

Bowman, J.J., Clabby, K.J., Lucey, J., McGarrigle, M.L. and Toner, P.F. 1996 Water quality in Ireland 1991-1994. Wexford. EPA.

Bozika, E. 2001 Phosphorus removal from wastewater using sludge from mine drainage treatment settling ponds. Unpublished MSc thesis, University of Edinburgh.

Bragato, C., Brix, H. and Malagoli, M. 2006 Accumulation of nutrients and heavy metals in Phragmites australis (Cav.) Trin. ex Steudel and Bolboschoenus maritimus (L.) Palla in a constructed wetland of the Venice lagoon watershed. Environmental Pollution 144, 967-75.

Carmichael, P.A. 1994 Using woodchips as a source of organic carbon in denitrification: column experiment and field study implementing the funnel and gate design. Unpublished MSc thesis, University of Waterloo, Ontario.

Clabby, K.J., Lucey, J., McGarrigle, M.L., Bowman, J.J., Flanagan, P.J. and Toner, P.F. 1992 Water quality in Ireland 1987-1990, part one: general assessment. Dublin. An Foras Forbartha.

Council of the European Union 1975 Council Directive 75/440/EEC of 16 June 1975 concerning the quality required of surface water intended for the abstraction of drinking water in the Member States. Official Journal of the European Communities L194, 2631.

Council of the European Union 1980 Council Directive 80/68/EEC of 17 December 1979 on the protection of groundwater against pollution caused by certain dangerous substances. Official Journal of the European Communities L20, 43-8.

Council of the European Union 1986 Council Directive 86/278/EEC of 12 June 1986 on the protection of the environment, and in particular of the soil, when sewage sludge is used in agriculture. Official Journal of the European Communities L181, 6-12.

Council of the European Union 1991a Council Directive 91/676/EEC of 21 May 1991 concerning the protection of waters against pollution caused by nitrates from agricultural sources. Official Journal of the European Communities L375, 1-8.

Council of the European Union 1991b Council Directive 91/271/EEC of 21 May 1991 concerning urban wastewater treatment. Official Journal of the European Communities L135, 40-52.

Council of the European Union 1998 Council Directive 98/83/EC of 3 November 1988 on the quality of water intended for human consumption. Official Journal of the European Communities L330/32, $32-54$.

Council of the European Union 1999 Council Directive 99/31/EC of 26 April 1999 on the landfill of waste. Official Journal of the European Communities L182, 1-19.

Council of the European Union 2000 Water Framework Directive 2000/60/EC establishing a framework for community action in the field of water policy, available at http://www.wfdireland.ie (15 November 2007).

CSO 2006 Livestock survey. February 2006, available at http://www.cso.ie (15 November 2007).

Daly, K., Jeffrey, D. and Tunney, H. 2001 The effect of soil type on phosphorus sorption capacity and desorption dynamics in Irish grassland soils. Soil Use and Management 17, 12-20.

Dawson, M. 2004 Opportunities for bioenergy from short-rotation crops - the resource and potential in 


\section{A REVIEW OF REMEDIATION AND CONTROL SYSTEMS}

Ireland. In Proceedings, wood energy conference, Cork, 78 October 2004. Dublin. COFORD.

Dayton, E.A. and Basta, N.T. 2005 Use of drinking water residuals as a potential best management practice to reduce phosphorous risk index scores. Journal of Environmental Quality 34, 2112-17.

Dayton, E.A., Basta, N.T., Jakober, C.A. and Hattey, J.A. 2003 Using treatment residuals to reduce phosphorous in agriculture run-off. Journal of the American Water Works Association 95, 151-8.

Department of Agriculture and Food 2003 Compendium of Irish agricultural statistics. Dublin. Department of Agriculture and Food.

Department of the Environment, Heritage and Local Government 1999 Code of good practice for the use of biosolids in agriculture - guidelines for local authorities and wastewater treatment plant operators, available at http://www.environ.ie/en/Publications/ Environment/Water (15 November 2007).

Dimitriou, I. and Aronsson, P. 2004 Nitrogen leaching from short-rotation willow coppice after intensive irrigation with wastewater. Biomass and Bioenergy 26, 433-41.

Dimitriou, I. and Aronsson, P. 2005 Willows for energy and remediation in Sweden. Unasylva 221, 47-50.

EPA 2004 Biological survey of river quality - results of the 2003 investigations. Wexford. EPA.

Erickson, A.E., Ellis, B.C., Tiedje, J.M., Wolcott, A.R., Hansen, C.M., Peabody, F.R., Miller, E.C. and Thomas, J.W. 1974 Soil modification for denitrification and phosphate reduction of feedlot waste. Washington, DC. EPA.

Fahner, S. 2002 Groundwater nitrate removal using a bioremediation trench. Unpublished MSc thesis, University of Western Australia.

Fenton, O., Healy, M.G. and Rodgers. M. 2007 Assessing the performance of phosphorus retention using an Avoca-Avonmore catchment ochre, Ireland. Paper presented at the Groundwater quality 2007: securing groundwater quality in urban and industrial environment conference, in Freemantle, Australia, 2-7 December 2007.

Fenton, O., Healy, M.G., Rodgers, M. and Richards, K. (in press) Methodology for the location of a subsurface permeable reactive barrier for remediation of point source pollution on an Irish farm. Tearmann.

Fingleton, W.A. and Cushion, M. 1999 Irish agriculture in figures 1998. Dublin. Teagasc.

Foundations for Water Research 2004 The feasibility of in situ groundwater remediation as robust low cost water treatment option. Report No. 1325/1/04, available at http://www.fwr.org (15 November 2007).

Gallimore, L.E., Basta, N.T., Storm, D.E., Payton, M.E., Hunke, R.H. and Smolen, M.D. 1999 Use of waste treatment residuals to reduce nutrients in surface run-off from agricultural land. Journal of Environmental Quality 28, 1474-8.

Gao, M., Yang, M., Li, H., Yang, Q. and Zhang, Y. 2004 Comparison between a submerged membrane bioreactor and a conventional activated sludge system on treating ammonia-bearing inorganic wastewater. Journal of Biotechnology 108, 265-9.
Gray, N.F. 1996 A substrate classification index for the visual assessment of the impact of acid mine drainage in lotic systems. Water Research 30, 1551-4.

Greenan, C.M., Moorman, T.B., Kaspar, T.C., Parkin, T.B. and Jaynes, D.B. 2006 Comparing carbon substrates for denitrification of subsurface drainage water. Journal of Environmental Quality 35, 824-9.

Haustein, L.E., Daniel, T.C., Miller, D.M., Moore, P.A, Jr., and McNew, R.W. 2000 Aluminium containing residuals influence high phosphorus soils and run-off quality. Journal of Environmental Quality 29, 1954-9.

Heal, K.V., Dobbie, K.E., Bozika, E., McHaffie, H., Simpson, A.E. and Smith, K.A. 2005 Enhancing phosphorus removal in constructed wetlands with ochre from mine drainage treatment. Water Science and Technology 51 (9), 275-82.

Healy, M.G., Rodgers, M. and Mulqueen, J. 2006 Denitrification of a nitrate-rich wastewater using various wood-based media materials. Journal of Environmental Science and Health, Part A: Toxic/ Hazardous Substances and Environmental Engineering 41, 1-10.

Healy, M.G., Newell, J. and Rodgers, M. 2007 Harvesting effects on biomass and nutrient retention in Phragmites australis in a free-water surface constructed wetland in western Ireland. Biology and Environment: Proceedings of the Royal Irish Academy 107B, 139-45.

Hodson, R.W., Slater, F.M., Lynn, S.F. and Randerson, P.F. 1993 Nutrient enhanced short-rotation coppice for biomass in central Wales. In Proceedings of the first biomass conference of the Americas: energy, environment, agriculture and industry, 296-301. Golden, Colorado. National Renewable Energy Laboratory.

Horn, D.A., Lamparski, H. and Wong, T.H.F. 2006 Groundwater treatment curtains to improve water quality in open drains. In A. Deletic and T. D. Fletcher (eds), Proceedings of 7th international conference on urban drainage modelling and the 4th international conference on water sensitive urban design, Melbourne, Victoria, 3-7 April 2006. Melbourne. Monash University.

Kalin, R.M. 2004 Engineered passive bioreactive barriers: risk-managing the legacy of industrial soil and groundwater pollution. Microbiology 7, $227-8$.

Karunaratne, S., Asaeda, T. and Yutani, K. 2004 Shoot regrowth and age-specific rhizome storage dynamics of Phragmites australis subjected to summer harvesting. Ecological Engineering 22, 99-111.

Kuai, L., Kerstens, W., Chong, N.P. and Verstraete, W. 1999 Treatment of domestic wastewater by enhanced primary decantation and subsequent naturally ventilated trickling filtration. Water, Air and Soil Pollution 113, 43-62.

Kung, K.-J.S., Kladivko, E.J., Gish, T.J., Steenhuis, T.S., Bubenzer, G. and Helling, C.S. 2000 Quantifying preferential flow by breakthrough of sequentially applied tracers: silt loam soil. Soil Science Society of America Journal 64, 1296-1304.

Lentz, R.D. and Sojka, R.E. 1992 Applying polymers to irrigation water: evaluating strategies for furrow erosion control. Transaction of the ASAE 43, 1561-8. 


\section{BIOLOGY AND ENVIRONMENT}

Lindoff Communications Ltd 2004 Recycling of wastewater and sludge in Salix plantations: sustainable and profitable use of waste resources and farmland in Europe for production of biofuels, available at http://www. biomatnet.org/publications/salix_se.pdf (15 November 2007).

Lucey, J., Bowmann, J.J., Cunningham, P., Lehane, M., MacCarthaigh, M., McCarrigle, M.L. and Toner, P.F. 1999 Water quality in Ireland 1995-1997. Wexford. EPA.

Mann, R.A. 1997 Phosphorus adsorption and desorption characteristics of constructed wetland gravels and steel work by-products. Australian Journal of Soil Resources 35, 375-84.

Mason, L.B., Amrhein, C., Goodson, C.C., Matsumoto, M.R. and Anderson, M.A. 2005 Reducing sediment and phosphorus in tributary waters with alum and polyacrylamide. Journal of Environmental Quality 34, 1998-2004.

McFarland, A.M.S., Hauck, L.M. and Kruzic, A.P. 2003 Phosphorus reductions in run-off and soils from land applied dairy effluent using chemical amendments: an observation. The Texas Journal of Agriculture and Natural Resource 16, 47-59.

McGarrigle, M.L., Bowman, J.J., Clabby, K.J., Lucey, J., Cunningham, P., MacCarthaigh, M., Keegan, M., Cantrell, B., Lehane, M., Clenaghan, C. and Toner, P.F. 2002 Water quality in Ireland 1998-2000. Wexford. EPA.

McGrath, D. and McCormack, R.J. 1999 The significance of heavy metals and organic micro-pollutants in soil-plant systems in Ireland. End of project report 4268. Wexford. Teagasc.

Moore, P.A., Jr., and Edwards, D.R. 2005 Longterm effects of poultry litter, alum-treated litter, and ammonium nitrate on aluminium availability in soils. Journal of Environmental Quality 34, 2104-11.

Moore, P.A., Jr., and Edwards, D.R. 2007 Longterm effects of poultry litter, alum-treated litter, and ammonium nitrate on phosphorus availability in soils. Journal of Environmental Quality 36, 163-74.

Moore, P.A., Jr., Daniel, T.C., Gilmour, J.T., Shreve, B.R., Edwards, D.R. and Wood, B.H. 1998 Decreasing metal run-off from poultry litter with aluminium sulfate. Journal of Environmental Quality 27, 92-9.

Moore, P.A., Jr., Daniel, T.C. and Edwards, D.R. 1999 Reducing phosphorus run-off and improving poultry production with alum. Poultry Science 78, 692-8.

Perttu, K.L. 1998 Environmental justification for short-rotation forestry in Sweden. Biomass and Bioenergy 15, 1-6.

Peters, J.M. and Basta, N.T. 1996 Reduction of excess bioavailable phosphorus in soils using municipal and industrial wastes. Journal of Environmental Quality 25, 1235-41.

Powell, R.M. and Powell, P.D. 1998 Iron metal for subsurface remediation. In R.A. Myers (ed), The encyclopaedia of environmental analysis and remediation, 4729-61. New York. John Wiley and Sons, Inc.

Rabah, F.K.J. and Dahab, M.F. 2004 Nitrate removal characteristics of high performance fluidized-bed biofilm reactors. Water Research 36, 3719-28.
Rice, B. 2003 Energy crops - have they a future?, available at http://www.teagasc.ie/publications/ 2003/conferences/nationaltillage/paper04.htm (30 January 2008).

River Basin Districts 2005 The characterisation and analysis of Ireland's river basin districts in accordance with section 7 (2\&3) of the European communities (water policy) regulations 2003 (SI 722 of 2003), available at http://www.wfdireland.ie/Documents/Characterisa tion\%20Report/Ireland_Article_5_WFD.pdf (30 January 2008).

Robertson, W.D. and Cherry, J.A. 1995 In-situ denitrification of septic system nitrate using reactive porous media barriers: field trials. Groundwater 33, 99111.

Robertson, W.D., Blowes, D.W., Ptacek, C.J. and Cherry, J.A. 2000 Long term performance of in situ reactive barriers for nitrate removal. Ground Water 38, 689 .

Rodgers, M. and Burke, D. 2002 Nitrogen removal using a vertically moving biofilm system. Water Science and Technology 47 (1), 71-6.

Rodgers, M., Zhan, X.-M. and Burke, M.D. 2004 Nutrient removal in a sequencing batch biofilm reactor (SBBR) using a vertically moving biofilm system. Environmental Technology 25, 211-18

Rosenquist, H. and Dawson, M. 2005 Economics of using wastewater irrigation of willow in Northern Ireland. Biomass and Bioenergy 29, 83-92.

Ryan, M. 1998 Better management and economy of the $N$ resource in grassland-relative denitrification rates in surface and subsurface mineral soil layers. Teagasc end of project report. Dublin. Teagasc.

Schipper, L.A. and Vojvodić-Vuković, M. 2001 Five years of nitrate removal, denitrification and carbon dynamics in a denitrification wall. Water Research 35, 3473-7.

Schipper, L.A., Barkle, G.F., Hadfield, J.C., VojvodićVuković, M. and Burgess, C.P. 2004 Hydraulic constraints on the performance of a groundwater denitrification wall for nitrate removal from shallow groundwater. Journal of Contaminant Hydrology 69, 263-79.

Schulte, R.P.O. 2006 Beyond the Nitrate Directive: new challenges for nutrient research, available at http://www. teagasc.ie/publications/tresearch/tresearch200611.pdf (15 November 2007).

Seong-Chun, J., Gwang-Ok, B., Kang-Kun, L. and Hyung-Jae, C. 2005 Identification of the source of nitrate contamination in ground water below an agricultural site. Journal of Environmental Quality 34, 804-15.

Simon, F.G. and Meggyes, T. 2000 Removal of organic and inorganic pollutants from groundwater using permeable reactive barriers. Land Contamination and Reclamation 8, 103-16.

Sims, J.T. and Luka-McCafferty, N.J. 2002 On-farm evaluation of aluminium sulfate (Alum) as a poultry litter amendment. Journal of Environmental Quality 31, 2066-73.

Sojka, R.E., Bjorneberg, D.L., Entry, J.A., Lentz, R.D. and Orts, W.J. 2007 Polyacrylamide in agriculture and environmental land management. Advances in Agronomy 92, 75-162. 


\section{A REVIEW OF REMEDIATION AND CONTROL SYSTEMS}

Suresh, B. and Ravishanker, G.A. 2004 Phytore mediation-a novel and promising approach for environmental clean-up. Critical Review Biotechnology 24, 97-124.

Toner, P., Bowman, J., Clabby, K., Lucey, J., McGarrigle, M., Concannon, C., Clenaghan, C., Cunningham, P., Delaney, J., O’Boyle, S., MacGarthaigh, M., Craig, M. and Quinn, R. 2005 Water quality in Ireland. Wexford. EPA.

Udeigwe, T.K., Wang, J.J. and Zhang, H. 2007 Predicting run-off of suspended solids and particulate phosphorus for selected Louisiana soils using simple soil tests. Journal of Environmental Quality 36, 1310-17.

USEPA 1990 Basics of Pump and Treat Ground Water Remediation Technology. EPA/600/8-90/003. Washington, DC. EPA.

Vanotti, M.B. and Hunt, P.G. 1999 Solids and nutrient removal from flushed swine manure using polacrylamides. Transactions of the ASAE 42, 183340.
Volokita, M., Belkin, S., Abeliovich, A. and Soares, M.I.M. 1996 Biological denitrification of drinking water using newspaper. Water Research 30, 96571.

Water4all 2005 Sustainable groundwater management, handbook of best practice to reduce agricultural impacts on groundwater quality, available at http://www. water4all.com/index.php?bereich $=$ news\&action $=$ show_News\&NewsID $=24 \&$ fro $\quad$ (November 15 2007).

WHO 2003 Aluminium in drinking water-background document for the development of WHO guidelines for drinking-water quality, available at http://www. who.int/water_sanitation_health/dwq/chemicals/alu minium/en/ (November 15 2007).

Zvomuya, F., Rosen, C.J. and Gruta, S.C. 2006 Phosphorus sequestration by chemical amendments to reduce leaching from wastewater applications. Journal of Environmental Quality 35, 207-15. 